Special Issue of the 8th International Advances in Applied Physics and Materials Science Congress (APMAS 2018)

\title{
Tribocorrosion Behaviour of Electroless Ni-P Coating on AA7075 Aluminum Alloy
}

\begin{abstract}
H. Mindivan*
Bilecik Seyh Edebali University, Department of Mechanical Engineering, 11210, Bilecik, Turkey

Electroless Ni-P coating was deposited on an AA7075 aluminum (Al) alloy, and its morphology, microhardness and tribocorrosion behaviour were evaluated. Coating characterization was done using light optic microscope (LOM) and field emission gun scanning electron microscope (FEG-SEM). Tribocorrosion tests were performed under open circuit potential (OCP) using a reciprocating ball-on-plate tribometer where a $10 \mathrm{~mm}$ diameter alumina ball was used as counter material and a normal load of $10 \mathrm{~N}$ was applied during $45 \mathrm{~min}$. The Ni-P coating's microhardness and tribocorrosion performance were higher than untreated alloy.
\end{abstract}

DOI: 10.12693/APhysPolA.135.1102

PACS/topics: AA7075 aluminum alloy, electroless Ni-P coating, tribocorrosion

\section{Introduction}

Aluminum and its alloys have been extensively used as a base material for many engineering applications due to their outstanding characteristics such as low density, high specific strength, excellent heat and electrical conductivities and low-specific weight etc. The thin porous natural oxide layer/passive film generated when aluminum alloys are exposed to air inhibits corrosion processes [1]. When exposed to a surface degradation process resulting from simultaneous action of corrosion and wear (i.e. tribocorrosion), however, this passive film may exhibit low wear or tribocorrosion resistance [2]. Wear-corrosion related problems are confronted as disadvantages in the use of these alloys.

Some surface engineering techniques have been developed to create a protective layer for applications involving harsh environments. Among these surface modification techniques, electroless nickel phosphorous $(\mathrm{Ni}-\mathrm{P})$ plating was considered as a promising surface treatment to mitigate tribocorrosion damage in this study due to its potential of attaining a combination of highly desirable properties such as low friction coefficient, high hardness, good wear and corrosion resistance [3], as well as its low deposition temperature that is compatible with heat sensitive light alloys.

In this work, the tribocorrosion behaviors of two typical materials, the AA7075 aluminum alloy and Ni-P coated AA7075 aluminum substrate, were investigated in the corroding media of solution of $3.5 \mathrm{wt} \% \mathrm{NaCl}$ at room temperature.

\section{Materials and equipments}

AA7075 disc-shaped samples with $25 \mathrm{~mm}$ diameter and $5 \mathrm{~mm}$ thickness were used as the substrate for the preparation of electroless $\mathrm{Ni}-\mathrm{P}$ coating. This grade was chosen

\footnotetext{
*e-mail: harun.mindivan@bilecik.edu.tr
}

because it is very popular in aeronautics. The aluminum attracts easily with oxygen, hence the fine layer is allow to form on the surface. Therefore, it is difficult to coat the aluminum substrates covered with a very thin and impervious oxide film, so suitable surface preparation (mechanical grinding and polishing, alkaline cleaning with acetone and methanol, acid pickling and pretreatment) is required [4]. The commercial Ni-P electroless solution (DURNI-COAT DNC 520-9) containing $5 \mathrm{~g} / \mathrm{L}$ nickel, $40 \mathrm{~g} / \mathrm{L} \mathrm{NaH}_{2} \mathrm{PO}_{2}$ and suitable amounts of additive and stabilizer were used. The stirring rate of plating bath for $120 \mathrm{~min}$ was about $250 \mathrm{r} / \mathrm{min}$, using a magnetic stirrer and a polytetrafluoroethylene (PTFE) coated magnet with $2 \mathrm{~cm}$ length and $5 \mathrm{~mm}$ in diameter. The deposition was carried out in a $250 \mathrm{ml}$ thermostated double wall beaker at $90^{\circ} \mathrm{C}$ and $\mathrm{pH} 4.6$ for $1 \mathrm{~h}$ to achieve a thickness of $13 \mu \mathrm{m}$.

The surface morphology and cross section of the coating were studied by a Zeiss Supra Field Emission Gun Scanning Electron Microscope (FEG-SEM) and a Nikon Eclipse LV150 Light Optic Microscope (LOM), respectively. Knoop indentation on polished cross section was used to obtain hardness values that are completely uninfluenced by the substrate hardness.

The tribocorrosion tests of the polished AA7075 aluminum substrate and $\mathrm{Ni}-\mathrm{P}$ coated sample were conducted in a triboelectrochemical cell containing $25 \mathrm{ml}$ of $3.5 \mathrm{wt} \% \mathrm{NaCl}$ solution by using a ball-on-disk reciprocating tribometer coupled with a three electrode electrochemical cell. Reciprocating sliding wear tests were performed in a reciprocating mode with a $1.7 \mathrm{~cm} / \mathrm{s}$ sliding rate under $10 \mathrm{~N}$ applied load for $45 \mathrm{~min}$ at open circuit potential (OCP) conditions. The OCP was measured before, during and after sliding where the sliding action started after reaching the stable OCP values for each test. The counter body was an $\mathrm{Al}_{2} \mathrm{O}_{3}$ ball with 10 $\mathrm{mm}$ diameter. The ball holder was made of a polymeric material to prevent the corrosion effects. During the test, surface with an area of $1.4 \mathrm{~cm}^{2}$ was exposed to the corrosive electrolyte. After tribocorrosion tests, the worn 
surfaces of the wear tracks that formed on the examined samples and corresponding $\mathrm{Al}_{2} \mathrm{O}_{3}$ balls were investigated by the FEG-SEM and LOM, respectively.

\section{Results and discussion}

Figure 1 depicts surface morphology of the $\mathrm{Ni}-\mathrm{P}$ coated sample and cross-sectional micrograph showing Knoop indentations across the coating. The coating with thickness of approximately $13 \mu \mathrm{m}$ was homogeneous and showed a relatively good adherence to the substrate (Fig. 1b). Because of the low amount of nodules on the Ni-P coated sample (Fig 1a), it seems that the Ni-P coated surface had a low roughness value $\mathrm{Ra}=0.17 \pm 0.01 \mu \mathrm{m}$. After electroless $\mathrm{Ni}-\mathrm{P}$ coating, a 7.4 fold increase in hardness $\left(586 \mathrm{HK}_{0.01}\right)$ was achieved compared to the untreated alloy not subjected to electroless deposition (78.5 $\mathrm{HK}_{0.01}$ ).

The evolution of the open circuit potential (OCP) with time before, during, and after the sliding is shown in Fig. 2, together with the coefficient of friction (COF) values recorded during the sliding and the wear track morphologies for the untreated alloy and $\mathrm{Ni}-\mathrm{P}$ coated sample and corresponding $\mathrm{Al}_{2} \mathrm{O}_{3}$ counter parts generated after generated after the sliding. Before sliding, the OCP values were stable in all samples due to the presence of a passive film on the sample surfaces in contact
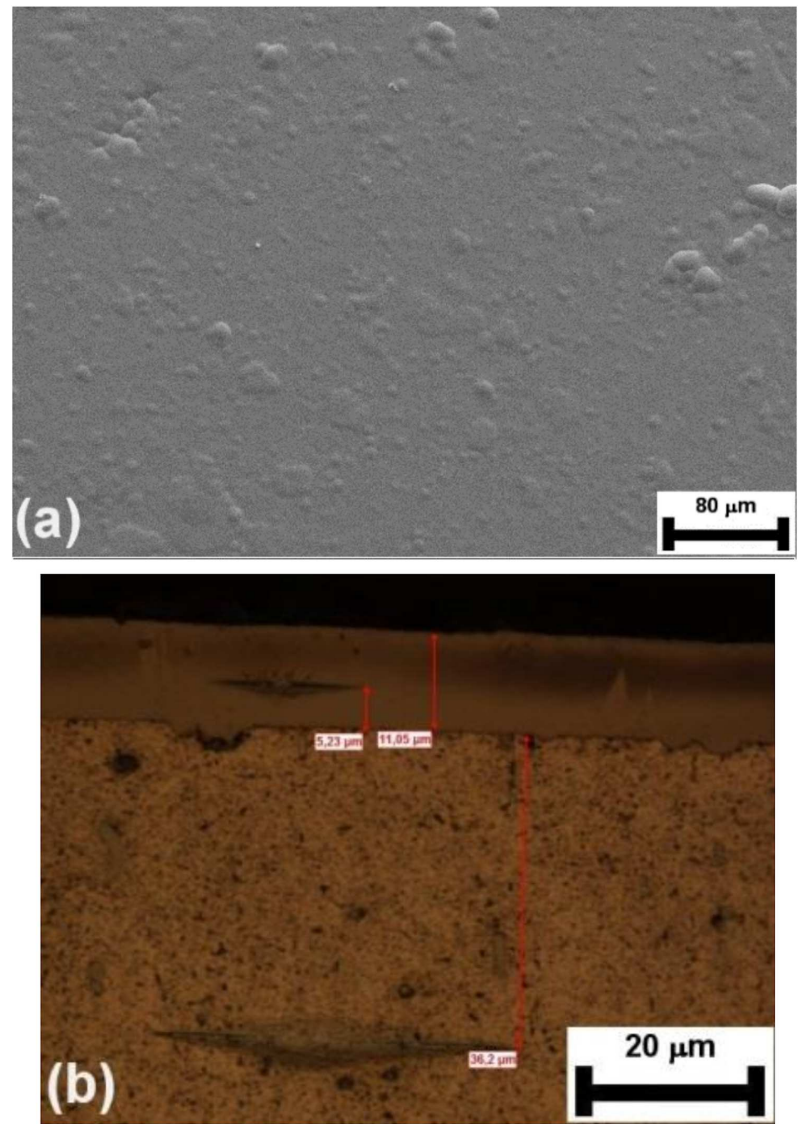

Fig. 1. (a) Surface morphology of the Ni-P coated sample and (b) cross-section LOM image showing Knoop indentations across the coating. with the electrolyte [5]. In the untreated alloy, when the sliding started, OCP values dropped down sharply, it means that the passive film becomes fully destroyed in presence of $3.5 \mathrm{wt} \% \mathrm{NaCl}$ solution under a high load of 10 N. During the sliding, the untreated alloy presented more negative OCP when compared to the $\mathrm{Ni}-\mathrm{P}$ coated sample (Fig. 2b). After sliding, OCP values increased up to near the initial values recorded before the sliding action due to the recovering of the passive film on the surface in the wear track [5]. However, an opposite behavior was observed for the Ni-P coated sample. When sliding started, instead of sharp drop, the OCP suddenly increased and then after a sudden drop in the OCP, the $\mathrm{Ni}-\mathrm{P}$ coated sample showed a constant value of approximately $-700 \mathrm{mV}$ for the first $\sim 1700 \mathrm{~s}$ of the friction test at load of $10 \mathrm{~N}$ (Fig. 2b). However, later on, a remarkable change in the friction coefficient with sliding time was observed (Fig. 2a) and this layer may get cracked (Fig. 2c), then cracked hard $\mathrm{Ni}-\mathrm{P}$ debris (i.e. third-body particles) resulted in a gradual decrease in the OCP along with fluctuations in the OCP after approximately 1700 $\mathrm{s}$ of the beginning of the sliding after provoking a third body. The delayed drop in the $\mathrm{Ni}-\mathrm{P}$ coated sample can be attributed to the increased hardness and corrosion resistance given by the $\mathrm{Ni}-\mathrm{P}$ layer $[3,4]$. The net reduction in the wear damage for the $\mathrm{Ni}-\mathrm{P}$ coated sample $/ \mathrm{Al}_{2} \mathrm{O}_{3}$ ball tribo-pair with respect to the untreated alloy $/ \mathrm{Al}_{2} \mathrm{O}_{3}$ ball tribo-pair can be directly seen in Fig. 2c and d.

\section{Conclusion}

The conclusions of this study are as follows:

1. $\mathrm{Ni}-\mathrm{P}$ coating on AA7075 Al alloy was prepared by electroless deposition. The cross-section view of the $\mathrm{Ni}-\mathrm{P}$ coating revealed that the coating was uniform, crack free and adherent metallic coating.

2. The hardness and tribocorrosion performance of the $\mathrm{Ni}-\mathrm{P}$ coating generated by electroless deposition were remarkably higher than those of the untreated sample.

\section{Acknowledgments}

The financial support of the research foundation of Bilecik Seyh Edebali University (Project no.: 201801.BŞEÜ.03-03) is gratefully acknowledged.

\section{References}

[1] U. Saglam, M. Baydogan, H. Mindivan, E.S. Kayalı, H. Çimenoglu, Z. Metallkd. 95, 14 (2004).

[2] H. Mindivan, M. Baydogan, E.S. Kayalı, H. Çimenoglu, Mater. Charact. 54, 263 (2005).

[3] B. Panja, S.K. Das, P. Sahoo, Surf. Rev. Lett. 23, 1 (2016).

[4] H. Mindivan, Machin. Technol. Mater. 6, 29 (2016).

[5] F. Mindivan, M.P. Yildirim, F. Bayindir, H. Mindivan, Acta Phys. Pol. A 129, 701 (2016). 


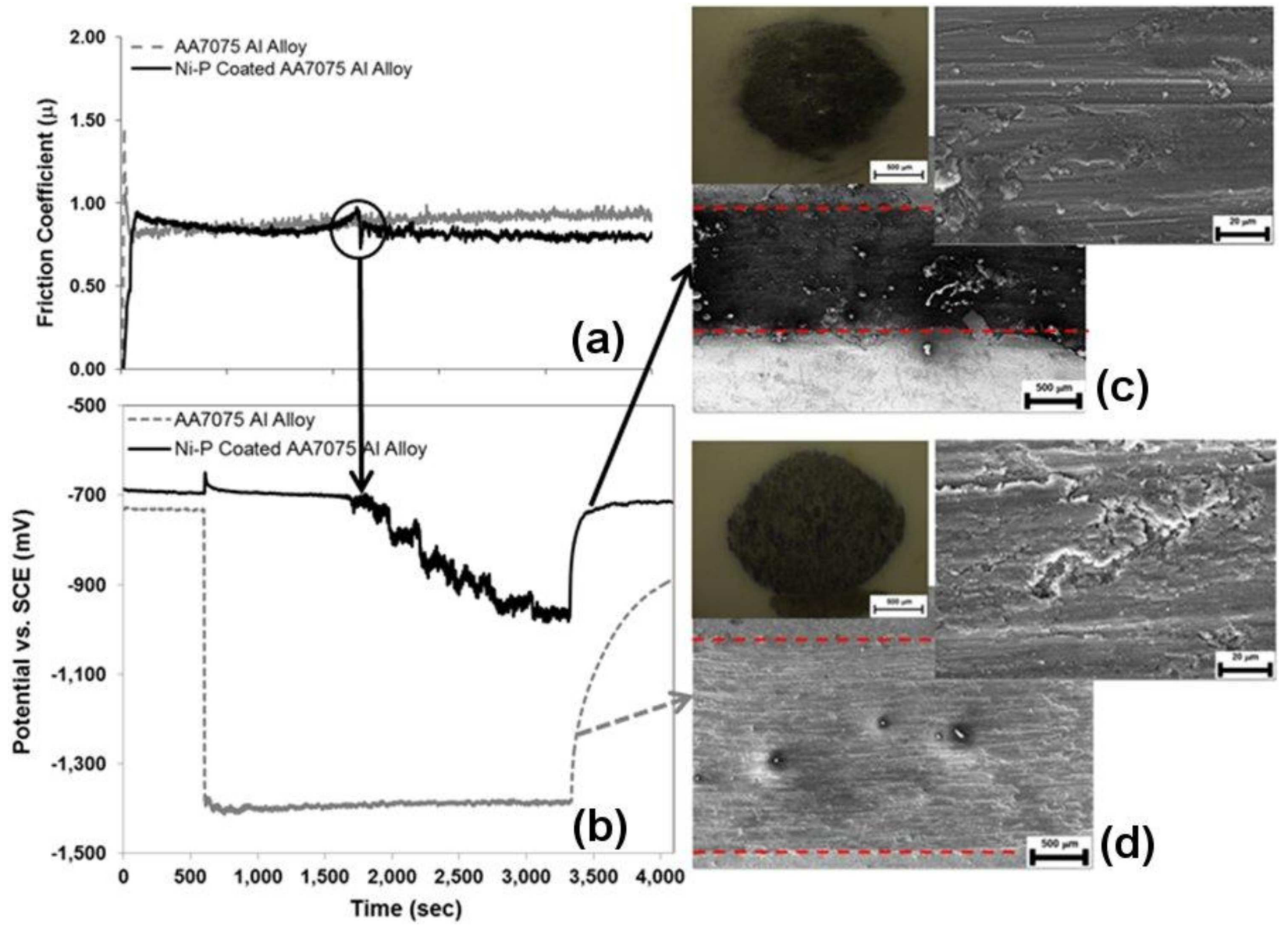

Fig. 2. Variation of (a) friction coefficient and (b) OCP recorded during the OCP tribocorrosion tests, (c, d) wear track morphologies for the examined samples and corresponding $\mathrm{Al}_{2} \mathrm{O}_{3}$ counter parts generated after the OCP tribocorrosion tests. 